Supporting information for

\title{
Phenyltetraene-Based Nonlinear Optical Chromophores with Enhanced Chemical Stability and Electro-Optic Activity
}

Jingdong Luo, ${ }^{a}$ Su Huang, ${ }^{a}$ Yen-Ju Cheng, ${ }^{a}$ Tae-Dong Kim, ${ }^{a}$ Zhengwei Shi, ${ }^{a}$

Xing-Hua Zhou, ${ }^{a}$ and Alex K-Y. Jen ${ }^{a, b^{*}}$

${ }^{a}$ Department of Materials Science \& Engineering, and ${ }^{b}$ Department of Chemistry

University of Washington, Seattle, WA 98195, U. S. A.

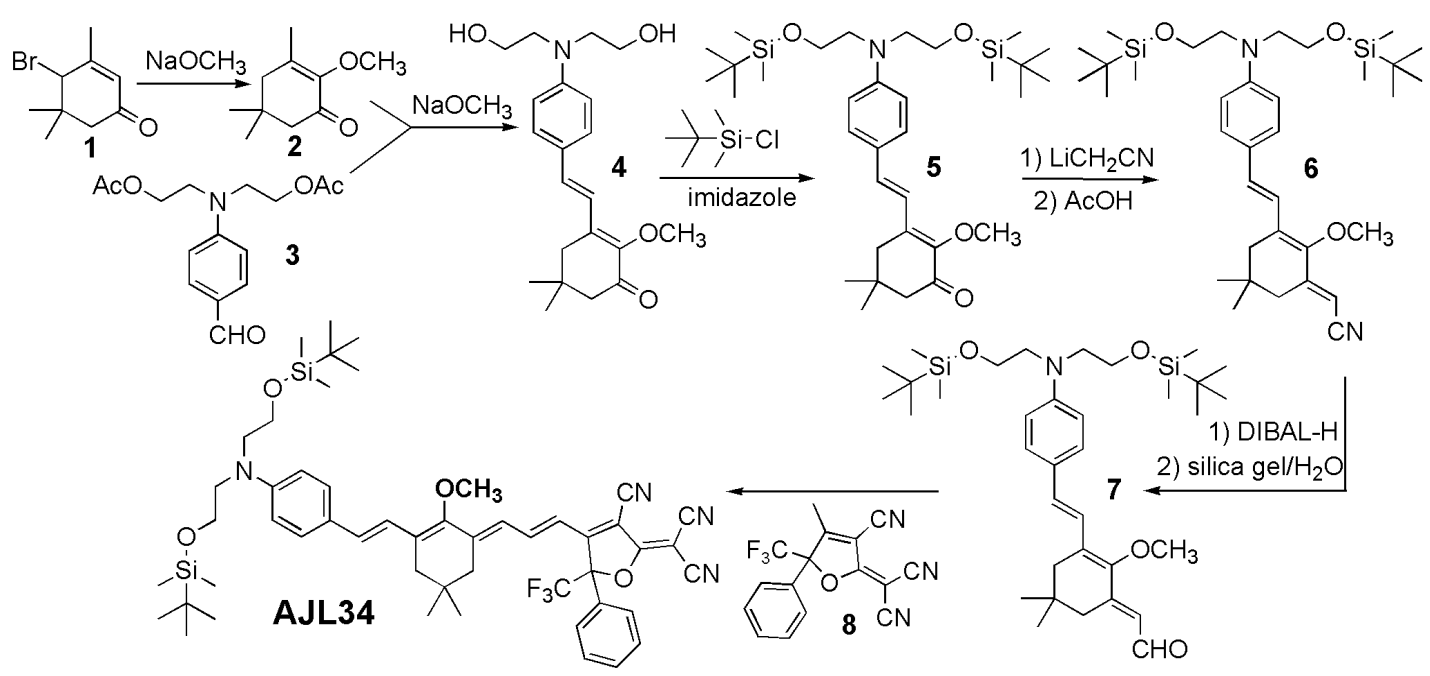

\section{General Procedures}

All reactions were carried out under inert nitrogen atmosphere unless otherwise specified. Solvents such as tetrahydrofuran (THF) and toluene were treated and distilled prior to use amLording to the common purification procedures. All the chemicals from Aldrich were used as received unless otherwise specified. Compounds 1, 2, 3, and 8 were prepared amLording to the literature procedures, respectively. ${ }^{1-4}{ }^{1} \mathrm{H}$ NMR and ${ }^{13} \mathrm{C}$ NMR spectra were taken on a Bruker AV-301 spectrometer $(300 \mathrm{MHz})$, and all the raw data were transferred by 1D NMR processor of ACDLABS 9.0. UV-vis-NIR spectra were obtained on a Perkin-Elmer Lambda-9 spectrophotometer and ESI-MS spectra were recorded on a Bruker Daltonics Esquire ion trap mass spectrometer. 
Preparation of compound 4 . To a freshly prepared solution of sodium methoxide $(\sim 0.10$ $\mathrm{mmol})$ in $30 \mathrm{~mL}$ of methanol was added dropwise the solution of compound $\mathbf{1}(2.17 \mathrm{~g}$, $0.01 \mathrm{mmol}$ ) in $6.0 \mathrm{~mL}$ of dry methanol. The mixture was stirred at $65{ }^{\circ} \mathrm{C}$ under the atmosphere of nitrogen and monitored by thin layer chromatography (TLC). The conversion from compound $\mathbf{1}$ to compound $\mathbf{2}$ was observed to be quantitative after 50 mins. To the same reaction pot, compound 3 (2.93 g, $0.01 \mathrm{mmol})$ was added and the reaction mixture was kept at $65^{\circ} \mathrm{C}$ for overnight. The crude product was collected via normal workup procedure. Compound 4 was obtained as thick reddish oil (1.6 g) by the purification of flash chromatography (silica gel; eluting with a gradient from ethyl acetate/hexane $(1: 1, \mathrm{v} / \mathrm{v})$ to ethyl acetate). ${ }^{1} \mathrm{H}$ NMR $\left(300 \mathrm{MHz}, \mathrm{CDCl}_{3}, \mathrm{TMS}, \mathrm{ppm}\right): \delta$ $7.40(\mathrm{~d}, J=8.6 \mathrm{~Hz}, 2 \mathrm{H}), 7.25(\mathrm{~d}, J=16.2 \mathrm{~Hz}, 1 \mathrm{H}), 6.81(\mathrm{~d}, J=16.2 \mathrm{~Hz}, 1 \mathrm{H}), 6.64(\mathrm{~d}, J=$ $8.7 \mathrm{~Hz}, 2 \mathrm{H}), 4.36$ (br s, 2H), 3.82 (t, $J=4.6 \mathrm{~Hz}, 4 \mathrm{H}), 3.75$ (s, 3H), 3.55 (t, $J=4.6 \mathrm{~Hz}$, 4H), 2.49 (s, 2H), 2.31 (s, 2H), 1.08 (s, 6H). $\left.{ }^{13} \mathrm{C} \mathrm{NMR} \mathrm{(75} \mathrm{MHz,} \mathrm{CDCl}_{3}, \mathrm{ppm}\right): \delta$ 194.9, 148.6, 147.6, 140.3, 135.0, 128.8, 125.2, 119.0, 112.4, 60.5, 55.1, 51.9, 38.8, 32.7, 28.4. ESI-MS (m/z): $360.5\left(\mathrm{M}+\mathrm{H}^{+}\right)$.

Preparation of Compound 5. The solid of tert-butyldimethylsilyl chloride ( $2.0 \mathrm{~g}, 0.013$ mol) was added to the mixture of compound 4 (1.0 g, $0.003 \mathrm{~mol})$ and imidazole (1.0 g, $0.015 \mathrm{~mol}$ ) in $5.0 \mathrm{~mL}$ of anhydrous dimethylformamide (DMF). After stirred at room temperature for an hour, the reaction mixture was poured into $50 \mathrm{~mL}$ of water and extracted with hexane $(20 \mathrm{~mL} \times 3)$. The combined extract was dried over sodium sulfate and condensed via rotary evaporation. The residue was purified with flash chromatography on silica gel using ethyl acetate/hexane (1/3, v:v) and recrystallized from methanol to afford compound 5 as a yellow solid (1.2 g, yield: 70\%). ${ }^{1} \mathrm{H}$ NMR (300 $\left.\mathrm{MHz}, \mathrm{CDCl}_{3}, \mathrm{ppm}\right): \delta 7.42(\mathrm{~d}, J=8.7 \mathrm{~Hz}, 2 \mathrm{H}), 7.29$ (d, $\left.J=16.2 \mathrm{~Hz}, 1 \mathrm{H}\right), 6.84(\mathrm{~d}, J=$ $16.2 \mathrm{~Hz}, 1 \mathrm{H}), 6.69$ (d, $J=8.7 \mathrm{~Hz}, 2 \mathrm{H}), 3.78$ (t, $J=6.3 \mathrm{~Hz}, 4 \mathrm{H}), 3.75$ (s, 3H), 3.56 (t, $J=$ $6.3 \mathrm{~Hz}, 4 \mathrm{H}), 2.54(\mathrm{~s}, 2 \mathrm{H}), 2.38(\mathrm{~s}, 2 \mathrm{H}), 1.06(\mathrm{~s}, 6 \mathrm{H}), 0.90(\mathrm{~s}, 18 \mathrm{H}), 0.05(\mathrm{~s}, 12 \mathrm{H}) .{ }^{13} \mathrm{C}$ NMR (75 MHz, $\left.\mathrm{CDCl}_{3}, \mathrm{ppm}\right): \delta 194.4,148.7,147.5,139.9,134.9,128.9,124.5,118.6$, $111.7,60.5,60.3,53.5,52.0,38.9,32.7,28.5,25.9,18.2,-5.3$. ESI-MS (m/z): 588.6 $\left(\mathrm{M}+\mathrm{H}^{+}\right)$. 
Preparation of Compound 6. A solution of freshly distilled (i-Pr $)_{2} \mathrm{NH}(0.328 \mathrm{~g}, 8.0$ $\mathrm{mmol})$ in dry THF $(5 \mathrm{~mL})$ was cooled to $-78^{\circ} \mathrm{C}$ and was maintained at this temperature during the dropwise addition of $n$-BuLi in hexane $(\sim 2.5 \mathrm{M}, 3.4 \mathrm{~mL}, \sim 8.0 \mathrm{mmol})$. After the mixture had been stirred at $-78^{\circ} \mathrm{C}$ for 15 minutes, it was warmed to $0{ }^{\circ} \mathrm{C}$ and held for 15 minutes. Then the solution was cooled back to $-78{ }^{\circ} \mathrm{C}$, and kept at this temperature during the dropwise addition of dry acetonitrile $(0.33 \mathrm{~g}, 8.1 \mathrm{mmol})$ in $4.0 \mathrm{~mL}$ of dry THF over $5 \mathrm{~min}$, followed after $10 \mathrm{~min}$, by the addition of a solution of compound $5(0.538 \mathrm{~g}$, $0.91 \mathrm{mmol})$ in dry THF $(5.0 \mathrm{~mL})$. The cooling bath of dry-ice/acetone was removed, and the reaction was allowed to equilibrate to $0{ }^{\circ} \mathrm{C}$ over $10 \mathrm{~min}$. Adding $10 \mathrm{~mL}$ of water dropwise to the solution of reaction mixture quenched the reaction. Roto-evaporation under reduced pressure removed most of organic solvent, and the residue was extracted by ethyl acetate $(50 \mathrm{~mL} \times 3)$. The combined organic layer was washed in turn with brine $(30 \mathrm{~mL} \times 2)$ and $\mathrm{DI}$ water $(50 \mathrm{~mL})$, and then dried over $\mathrm{Na}_{2} \mathrm{SO}_{4}$, filtered, evaporated to give the crude product of carbinol intermediate. Its solution in $4.0 \mathrm{~mL}$ of glacial acetic acid was stirred at $75{ }^{\circ} \mathrm{C}$ for $2 \mathrm{hrs} .{ }^{5}$ Then the reaction mixture was diluted by $100 \mathrm{~mL}$ of $\mathrm{CH}_{2} \mathrm{Cl}_{2}$, and neutralized by saturated aqueous solution of sodium bicarbonate. The organic layer was collected, concentrated, and purified by flash chromatography (silica gel; ethyl acetate/hexane $=1: 3, \mathrm{v} / \mathrm{v})$ to give compound $\mathbf{6}$ as an orange solid $(0.510 \mathrm{~g}$, yield: 92\%). ${ }^{1} \mathrm{H}$ NMR (300 MHz, $\left.\mathrm{CDCl}_{3}, \mathrm{ppm}\right): \delta 7.37(\mathrm{~d}, J=8.7 \mathrm{~Hz}, 2 \mathrm{H}), 7.15$ (d, $J=$ $16.2 \mathrm{~Hz}, 1 \mathrm{H}), 6.70(\mathrm{~m}, 3 \mathrm{H}), 5.50(\mathrm{~s}, 1 \mathrm{H}), 3.78(\mathrm{t}, J=6.3 \mathrm{~Hz}, 4 \mathrm{H}), 3.66(\mathrm{~s}, 3 \mathrm{H}), 3.56(\mathrm{t}, J$ $=6.3 \mathrm{~Hz}, 4 \mathrm{H}), 2.56(\mathrm{~s}, 2 \mathrm{H}), 2.38(\mathrm{~s}, 2 \mathrm{H}), 1.06(\mathrm{~s}, 6 \mathrm{H}), 0.90(\mathrm{~s}, 18 \mathrm{H}), 0.02(\mathrm{~s}, 12 \mathrm{H}) .{ }^{13} \mathrm{C}$ NMR (75 MHz, $\left.\mathrm{CDCl}_{3}, \mathrm{ppm}\right): \delta 153.2,148.7,148.6,132.8,131.1,128.7,125.0,119.0$, $111.9,89.7,61.2,60.6,53.8,42.9,39.3,31.0,28.3,26.2,18.5,-5.11$. ESI-MS (m/z): $611.5\left(\mathrm{M}+\mathrm{H}^{+}\right)$.

Preparation of Compound 7. The solution of compound $6(0.490 \mathrm{~g}, 0.80 \mathrm{mmol})$ in 6.0 $\mathrm{mL}$ of dry toluene was cooled to $-78^{\circ} \mathrm{C}$ and the solution of DIBAL in hexane (1.0 M, 1.4 $\mathrm{mL}, 1.4 \mathrm{mmol}$ ) was added dropwise. After being kept at $-78{ }^{\circ} \mathrm{C}$ for $1 \mathrm{hr}$, wet silica gel $(\sim 1.0 \mathrm{~g})$ with $3.0 \mathrm{~mL}$ of diethyl ether was added and the reaction mixture was stirred at 0 
${ }^{\circ} \mathrm{C}$ for 15 mins. Roto-evaporation removed most of low b.p. solvent, and the residue mixture was purified by flash chromatography (silica gel; ethyl acetate/hexane $=1: 3, \mathrm{v} / \mathrm{v}$ ) to give compound 7 as red solid (0.23 g, yield: 60\%). ${ }^{1} \mathrm{H} \mathrm{NMR}\left(300 \mathrm{MHz}, \mathrm{CDCl}_{3}, \mathrm{ppm}\right)$ : $\delta 10.10(\mathrm{~d}, J=8.4 \mathrm{~Hz}, 1 \mathrm{H}), 7.39$ (d, $J=8.9 \mathrm{~Hz}, 2 \mathrm{H}), 7.24$ (d, $J=16.2 \mathrm{~Hz}, 1 \mathrm{H}), 6.72(\mathrm{~d}, J$ $=15.90 \mathrm{~Hz}, 1 \mathrm{H}), 6.69(\mathrm{~d}, J=8.7 \mathrm{~Hz}, 2 \mathrm{H}), 6.33(\mathrm{~d}, J=7.5 \mathrm{~Hz}, 1 \mathrm{H}), 3.79$ (t, $J=6.3 \mathrm{~Hz}$, 4H), $3.67(\mathrm{~s}, 3 \mathrm{H}), 3.56(\mathrm{t}, J=6.3 \mathrm{~Hz}, 4 \mathrm{H}), 2.76(\mathrm{~s}, 2 \mathrm{H}), 2.42(\mathrm{~s}, 2 \mathrm{H}), 1.09$ (s, 6H), $0.90(\mathrm{~s}$, $18 \mathrm{H}), 0.05$ (s, 12H). ${ }^{13} \mathrm{C} \mathrm{NMR}\left(75 \mathrm{MHz}, \mathrm{CDCl}_{3}, \mathrm{ppm}\right): \delta 191.1,151.1,149.5,148.4$, $132.6,128.5,124.9,121.7,119.4,111.7,61.0,60.3,53.5,39.2,38.9,30.7,28.3,25.9$, 18.3, -5.3. ESI-MS (m/z): $614.5\left(\mathrm{M}+\mathrm{H}^{+}\right)$.

Preparation of Chromophore AJL34. The donor bridge 7 (0.21 g, $0.33 \mathrm{mmol})$ and acceptor $8(0.13 \mathrm{~g}, 0.40 \mathrm{mmol})$ were mixed together with anhydrous ethanol $(1.0 \mathrm{~mL})$. The reaction mixture was allowed to stir at $65^{\circ} \mathrm{C}$ for about 20 minutes and monitored by TLC. Roto-evaporation under reduced pressure removed the solvent, and the residue mixture was purified by flash chromatography twice (silica gel; eluting with a gradient of 25-35\% of ethyl acetate in hexane) to give chromophore AJL34 as a dark solid (0.20 g, yield 66\%). ${ }^{1} \mathrm{H}$ NMR (300 MHz, $\left.\mathrm{CDCl}_{3}, \mathrm{ppm}\right): \delta 8.02$ (t, $\left.J=14.5 \mathrm{~Hz}, 1 \mathrm{H}\right), 7.54$ (br m, $5 \mathrm{H}), 7.43(\mathrm{~d}, J=8.9 \mathrm{~Hz}, 2 \mathrm{H}), 7.28(\mathrm{~d}, J=15.9 \mathrm{~Hz}, 1 \mathrm{H}), 6.98(\mathrm{~d}, J=15.9 \mathrm{~Hz}, 1 \mathrm{H}), 6.89$ $(\mathrm{d}, J=15.9 \mathrm{~Hz}, 1 \mathrm{H}), 6.75$ (d, $J=14.4 \mathrm{~Hz}, 1 \mathrm{H}), 6.71(\mathrm{~d}, J=8.9 \mathrm{~Hz}, 1 \mathrm{H}), 6.45(\mathrm{~d}, J=$ $14.4 \mathrm{~Hz}, 1 \mathrm{H}), 3.80(\mathrm{t}, J=6.3 \mathrm{~Hz}, 4 \mathrm{H}), 3.70(\mathrm{~s}, 3 \mathrm{H}), 3.60(\mathrm{t}, J=6.0 \mathrm{~Hz}, 4 \mathrm{H}), 2.46(\mathrm{~s}, 2 \mathrm{H})$, 2.32 (q, $J=15.6 \mathrm{~Hz}, 2 \mathrm{H}), 1.04$ (s, 3H), 0.98 (s, 3H), 0.90 (s, 18H), $0.05(\mathrm{~s}, 12 \mathrm{H}) .{ }^{13} \mathrm{C}$ NMR (75 MHz, $\left.\mathrm{CDCl}_{3}, \mathrm{ppm}\right): \delta 175.7,162.2,151.9,151.4,149.5,146.6,138.7,136.4$, $131.2,130.2$, 129.6, 126.8, 124.8, 123.5, 119.3, 116.6, 112.0, 111.7, 111.4, 110.9, 61.6, $60.4,57.3,53.6,40.0,39.3,31.0,28.4,27.9,25.9,18.2,-5.3$. ESI-MS (m/z): 911.2 $\left(\mathrm{M}+\mathrm{H}^{+}\right)$.

\section{References:}

1. Edgar, A. J. B.; Harper, S. H.; Kazi, M. A. J. Chem. Soc. 1957, 1083.

2. Tsuboi, S.; Kurihara, Y.; Watanabe, T.; Takeda, A. Synth. Comm. 1987, 17, 773. 
3. Shen, Yuquan; Zhao, Yuxia; Li, Zao; Wang, Jianghong; Qiu, Ling; Liu, Shixiong; Zhai, Jianfeng; Zhou, Jiayun. J. Chem. Soc., Perkin Trans. 1: Organic and BioOrganic Chemistry 1999, 24, 3691.

4. a) Liu, S.; Haller, M. A.; Ma, H.; Dalton, L. R.; Jang, S.-H.; Jen, A. K.-Y. $A d v$. Mater. 2003, 15 (7-8), 603. b) He, M.; Leslie, T. M.; Sinicropi, J. A. Chem. Mater. 2002, 14 (5), 2393.

5. Luo, J.; Cheng, Y.-J.; Kim, T.-D.; Hau, S.; Jang, S.-H.; Shi, Z.; Zhou, X.-H.; Jen, A. K-Y. Org. Lett. 2006, 8, 1387.

Table 1. Selected linear (absorption maximum, $\lambda_{\max }$ ) and nonlinear optical data for phenyltetraene-based chromophores.

\begin{tabular}{cccc}
\hline & AJL34 & AJLS102 & YLD124 \\
\hline$\lambda_{\max }(\mathrm{nm})(1,4$-dioxane $)$ & 716 & 717 & 716 \\
$\lambda_{\max }(\mathrm{nm})($ chloroform $)$ & 792 & 792 & 787 \\
$\lambda_{\max }(\mathrm{nm})(\text { films with APC })^{a}$ & 794 & 796 & 788 \\
$r_{33}(\mathrm{pm} / \mathrm{V})$ values in poled & 137 & 105 & $\mathrm{~N} / \mathrm{A}$ \\
guest-host APC $^{b}$ & & & \\
\hline
\end{tabular}

${ }^{a}$ All the films were spin-coated from the cyclopentanone solution of the chromophore and amorphous polycarbonate (APC) $(1: 3, \mathrm{w} / \mathrm{w})$, and baked at $85^{\circ} \mathrm{C}$ overnight;

${ }^{b}$ The chromophore loading was at $25 \mathrm{wt} \%$, and the poling voltage was $1.0 \mathrm{MV} / \mathrm{cm}$. The $r_{33}$ values were measured by Teng-Man simple reflection technique at the wavelength of $1310 \mathrm{~nm}$. 
${ }^{1} \mathrm{H}$ NMR and ${ }^{13} \mathrm{C}$ NMR spectra
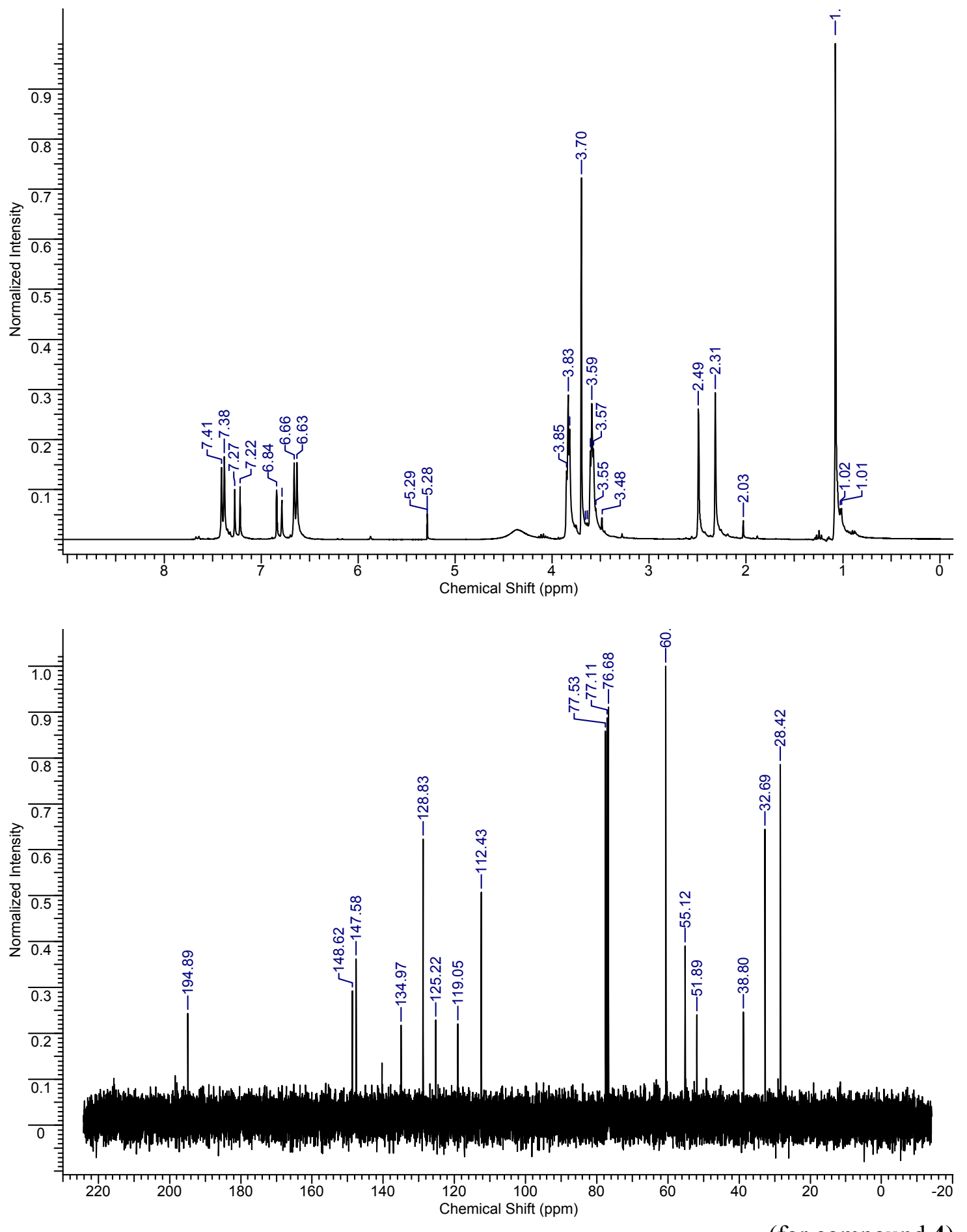

(for compound 4) 

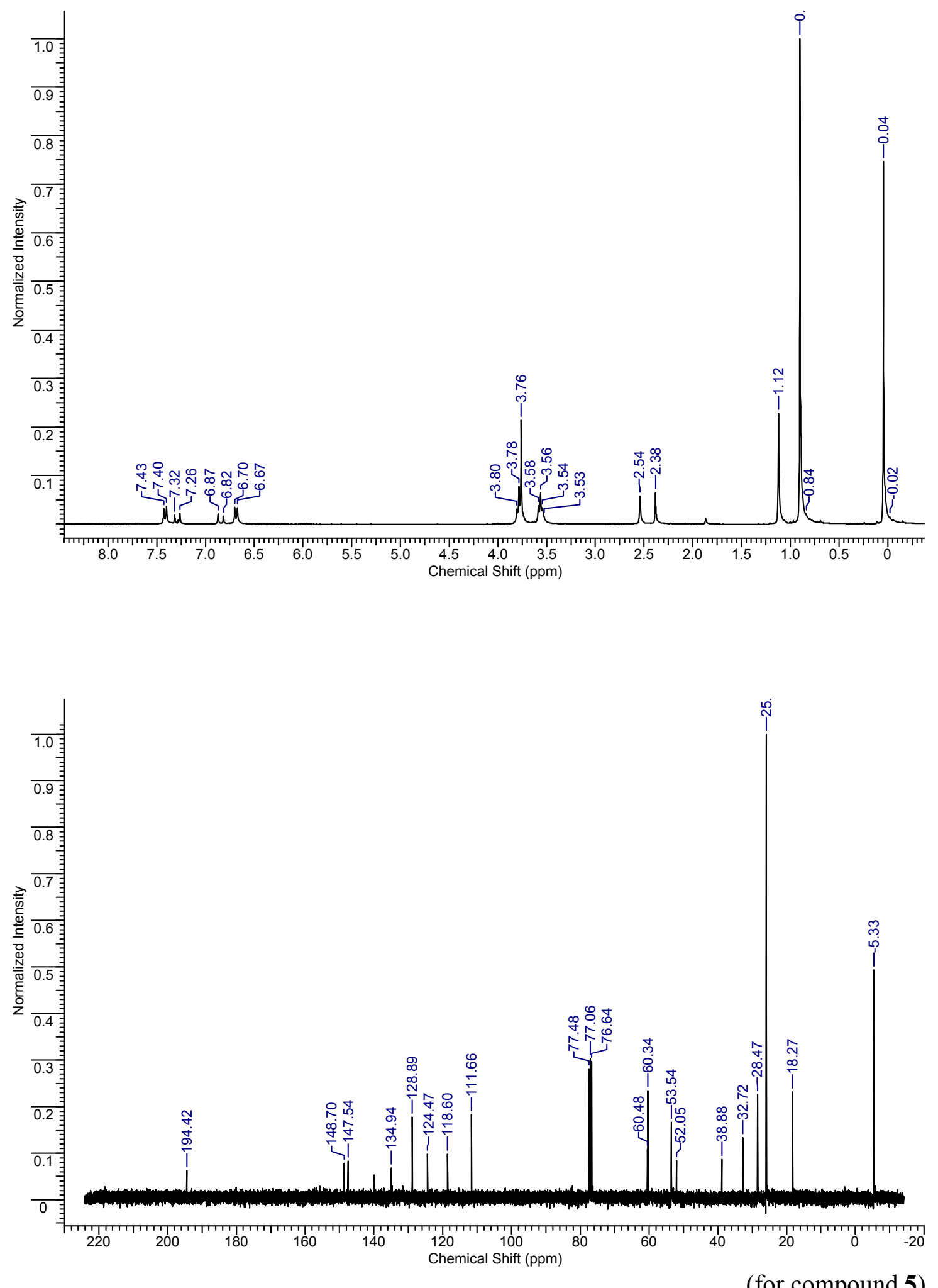

(for compound 5) 

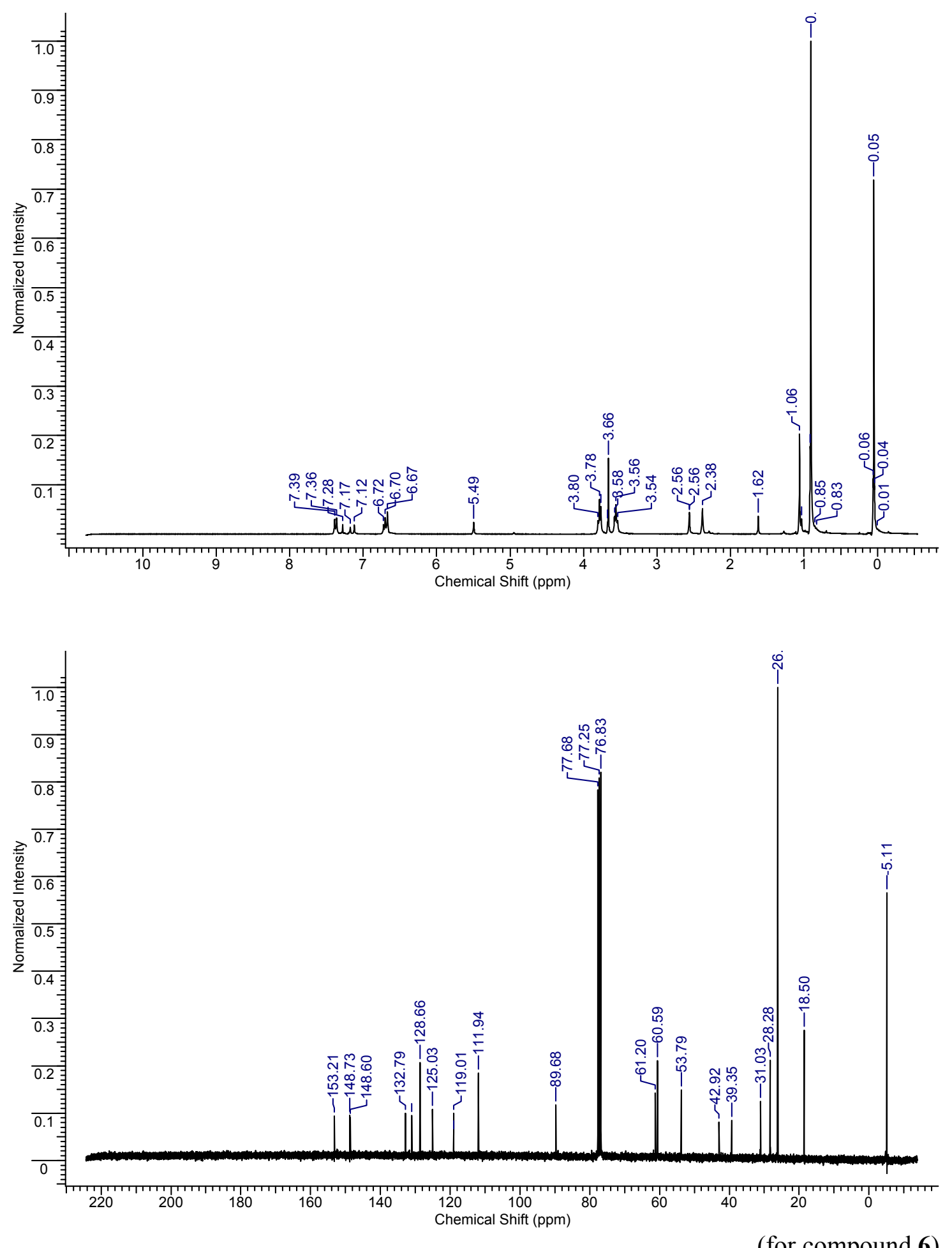

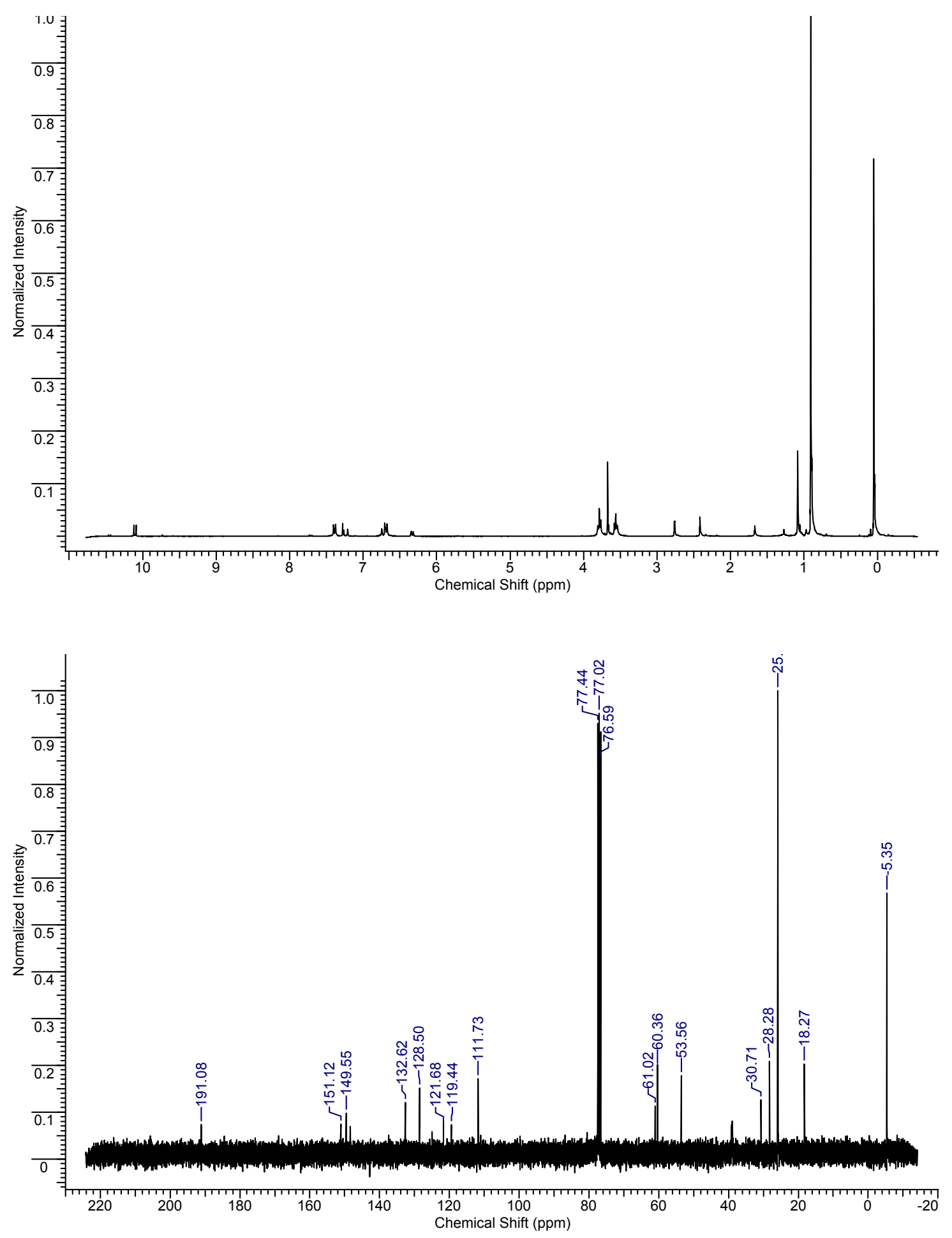

(for compound 7) 

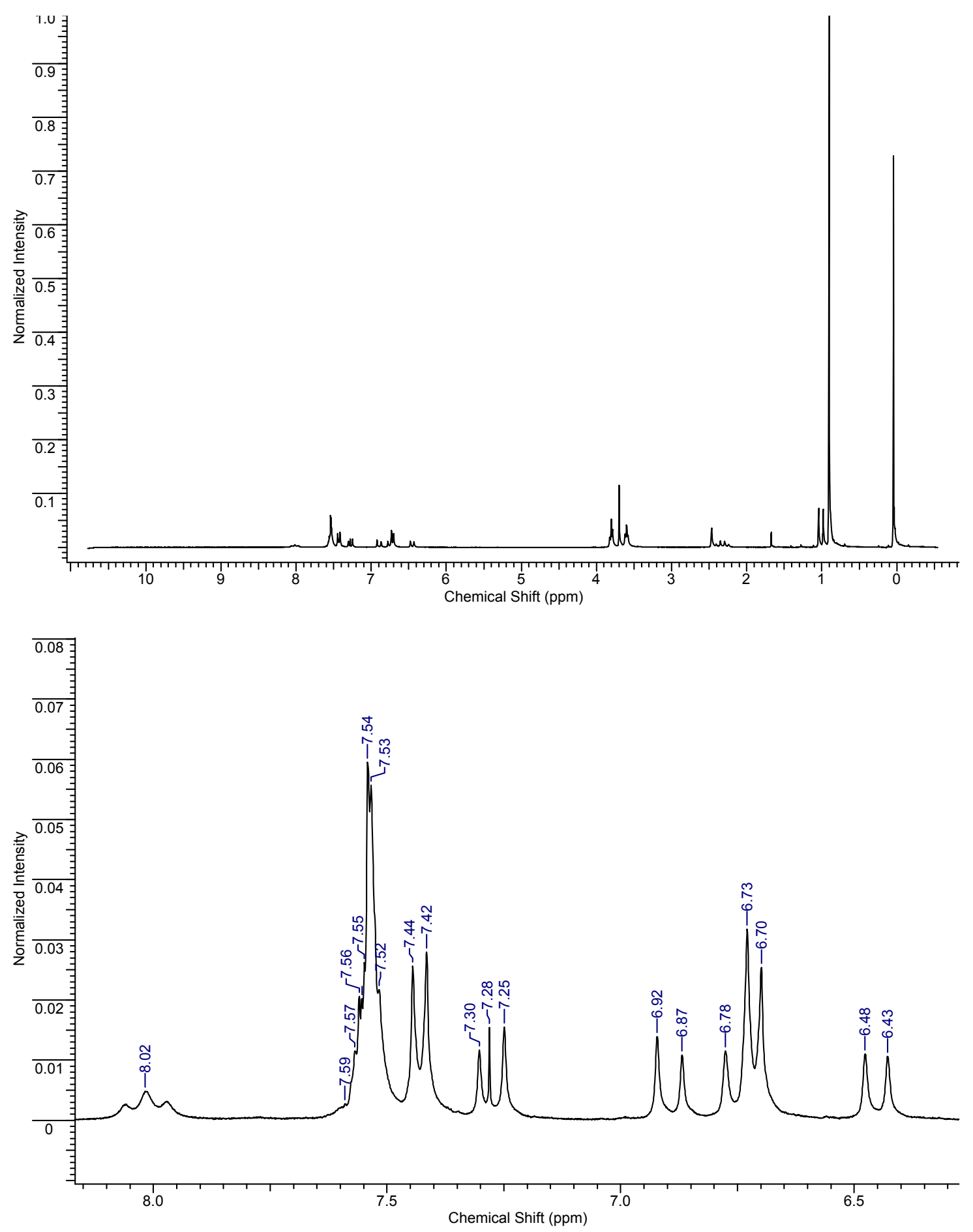

(for chromophore AJL34) 

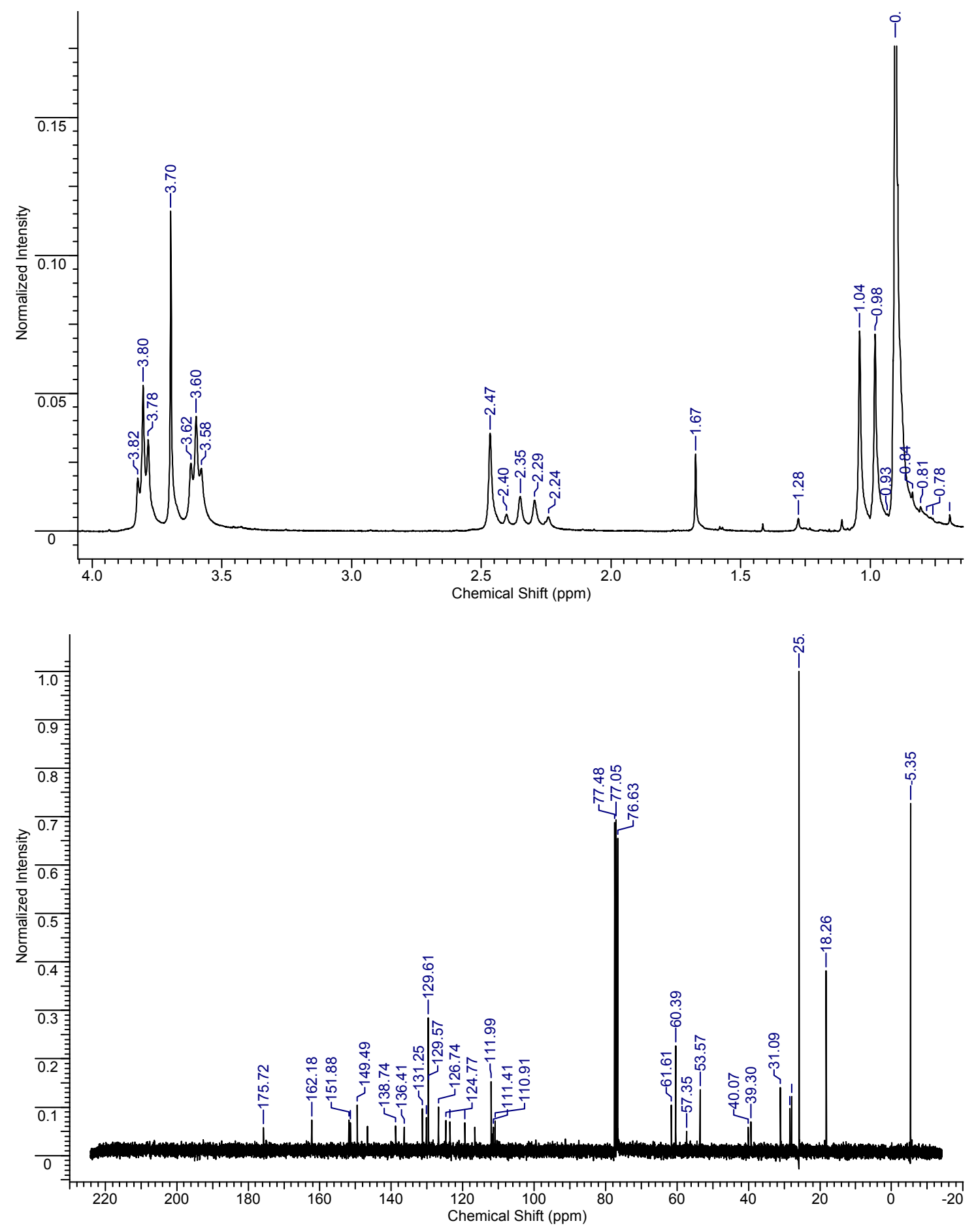

(for chromophore AJL34) 